\title{
DERADICALIZATION THROUGH ISLAMIC EDUCATION AT STATE INSTITUTE FOR ISLAMIC STUDIES (IAIN) TULUNGAGUNG
}

\author{
Ngainun Naim \\ State Institute for Islamic Studies (IAIN) Tulungagung \\ J. Mayor Sujadi Timur 46 Tulungagung 6622, East Java, Indonesia \\ E-mail: naimmas22@iain-tulungagung.ac.id
}

\begin{abstract}
Deradicalization Through Islamic Education at State Institute for Islamic Studies (IAIN) Tulungagung. This study aims to explain the role of islamic education as deradicalization stategy. The phenomenon of radical Islamism that is increasingly lively has caused unrest in society at large. If no efforts are made to anticipate, it is feared that the ideology of radical Islamism will be increasingly widespread and cause various negative implications in people's lives. Deradicalization is an important step to detect, neutralize and restore religious understanding from radical to moderate. The conclusion of this paper shows that the deradicalisation program at State Institute for Islamic Studies (IAIN) Tulung Agung was carried out with seven models, namely First, presenting speakers from the National Counterterrorism Agency (BNPT). Second, developing a non-formal Islamic education program (Madrasah Diniyah [Madin]) system. Third, fortifying the entry of radical Islamism through rules. Fourth, supporting all activities related to understanding and spreading moderate Islam. Fifth, take advantage of every opportunity that allows to explain the importance of moderate Islam. Sixth, optimizing local wisdom. Seventh, creating a learning environment that supports deradicalization programs.
\end{abstract}

Keywords: deradicalization; Islamic education, IAIN Tulungagung.

\begin{abstract}
Abstrak: Deradikalisasi Melalui Pendidikan Islam di Institut Agama Islam Negeri (IAIN) Tulungagung. Tulisan ini bertujuan menjelaskan tentang peran pendidikan Islam sebagai strategi deradikalisasi. Fenomena Islam radikal yang semakin semarak telah menimbulkan keresahan di masyarakat secara luas. Jika tidak dilakukan berbagai upaya antisipasi, dikhawatirkan ideologi Islam radikal akan semakin berkembang luas dan menimbulkan berbagai implikasi negatif dalam kehidupan masyarakat. Deradikalisasi merupakan langkah penting untuk mendeteksi, menetralisir, dan mengembalikan pemahaman keberagamaan dari radikal menjadi moderat. Kesimpulan tulisan ini menunjukkan bahwa program deradikalisasi di Institut Agama Islam Negeri (IAIN) Tulung Agung dilakukan dengan tujuh model, yaitu Pertama, menghadirkan narasumber dari Badan Nasional Penanggulangan Terorisme (BNPT). Kedua, Mengembangkan sistem Madrasah Diniyah (Madin). Ketiga, membentengi masuknya Islam radikal melalui aturan. Keempat, mendukung semua kegiatan yang berkaitan dengan pemahaman dan penyebaran Islam moderat. Kelima, memanfaatkan setiap kesempatan yang memungkinkan untuk menjelaskan pentingnya Islam moderat. Keenam, mengoptimalisasikan kearifan lokal. Ketujuh, menciptakan lingkungan pembelajaran yang mendukung program deradikalisasi.
\end{abstract}

Kata kunci: deradikalisasi; pendidikan Islam; IAIN Tulungagung.

\section{Introduction}

Since the reformation era, Islam in Indonesia has experienced quite interesting dynamics. Various of styles, characters, and variants of Islam grow rapidly. This dynamic development of Islam is the antithesis of Orde Baru (New Order) authoritarian policy towards Islam. During this period, Islam was under the government's thumb. It gave very strict control over various
Islamic movements that Islamic political parties were should be cut down. All activities emerged to challenge since religious social organizations and activities were closely monitored as well as strict control causes various expressions of Islam could not established optimally. ${ }^{1}$ Therefore, as

1 Faisal Ismail, Panorama Sejarah Islam dan Politik di Indonesia, Sebuah Studi Komprehensif, (Yogyakarta: IRCISoD, 2017), p. 278. 
the New Order collapsed, various expressions of Islam flourished. Various faces of Islam emerged, ranging from the liberal, moderate till the radical. Each expresses himself freely.

One form of religious movements that needs further observation is Islamic radical. Siti Mahmudah Noorhayati stated that religious radicalism emerge after the bombing was being confined and suppressed during New Order period". ${ }^{2}$ This statement implicitly shows that Islamic radical groups are growing. This development turned out to have a extensive influence on socio-religious life in Indonesia.

One important thing that should be seen from Islamic radical movements is their orientation. According to Azra, the orientation of such movements is 'Islamic State'. The desire the establishment of an Islamic state occurs while Indonesia's mainstream Islamic movements have long abandoned such an orientation. ${ }^{3}$ This kind of orientation is important to get an attention because it interferes the existing national buildings.

If we observe that Islamic radical movements can be categorized as minority groups. Nevertheless, their actions and struggles are enough to color the dynamics of socio-religious life in Indonesia. Media coveraged the quite dominated activities of this movements which suggests their existence in society.

Previous studies of Islamic radical movements show that this group is not the one. There are many movements in Islamic radical community which each of them has their unique vision, orientation, and direction of the movement, even one another is not infrequently involved in conflict. ${ }^{4}$ Studies and research on Islamic radical groups have been eventually intensified. However, there are differences lies on definitions and parameters among

\footnotetext{
2 Siti Mahmudah Noorhayati, "Pendidikan Multikultural di Pesantren (Upaya Membendung Radikalisme di Indonesia)", Madania Vol. 21, No. 1, 2017, p. 72.

${ }^{3}$ Azyumardi Azra, "Sekapur Sirih: Politik Islam Indonesia Kontemporer", in Sri Yunanto, Islam Moderat vs Islam Radikal, Dinamika Politik Islam Kontemporer, (Yogyakarta: Media Pressindo, 2018), p. vii.

4 Rubaidi, "Variasi Gerakan Radikal Islam di Indonesia", Analisis Vol. 11, No. 1, 2017, p. 33.
}

experts concerning the origin of Islamic radical movements. Nonetheless, from the previous studies, the present study agrees exclusive and legitimizing use of violence.

Violence is not a sudden phenomenon. In terms of Islamic radical, violence occurs because of the understanding of religious teachings that is interrelated with various factors, then systematically constructed. ${ }^{5}$ This phenomenon shows that there is a process in order to make people or groups have such characters. The process of radicalization occurs through many stages in a sustainable manner.

Bambang Sugiharto called such phenomenon as "Destructive Tendencies". This radicalization has implications for the emergence of exclusive groups, excessive moralistic attitudes, narrow and superficial consumerism of symbols, or frightening fanatical ritualism. ${ }^{6}$ This reality has caused anxiety from many parties. Haidar Bagir said that Indonesia is moving towards culturalism?. In fact, culture is a matter of humans. In relation with this culture, human is being captured with various points of view for example as spiritual being, moral being, aesthetic being, aware and critical thinking being. Islamic radical eliminates many human dimensions that are the character of culture.

Islamic radical groups generally do not develop open communication. They limit the social interaction and focus on communication within the group. In addition, they have strong compliance with their leaders. Members obedient on the leader commands. After New Order collapsed, such groups continue to establish eventually they are a lot. Because they are exclusive and familiar with violence, their movements lead to public unrest. ${ }^{8}$

5 Abd. A'la, "The Genealogy of Muslim Radicalism in Indonesia: A Study of the Roots and Characteristics of the Padri Movement", Journal of Indonesian Islam Vol. 2, No. 2, 2008, p. 268.

${ }^{6}$ Bambang Sugiharto, "Ilmu dan Agama dalam Kurikulum Perguruan Tinggi”, in Zainal Abidin Bagir, Jarot Wahyudi, and Afnan Anshori (eds.), Integrasi Ilmu dan Agama, Interpretasi dan Aksi, (Bandung: Mizan, 2005), p. 44.

7 Haidar Bagir, Islam Tuhan Islam Manusia: Agama dan Spiritualitas di Zaman Kacau, (Bandung: Mizan, 2017), p. 27.

${ }^{8} \mathrm{Abu}$ Rokhmad, “Radikalisme Islam dan Upaya Deradikalisasi Paham Radikal”, Walisongo, Jurnal Penelitian Sosial Keagamaan 
The increasing massive development of Islamic radical groups emerge to challenge for Indonesian. Exclusive character and legitimate violence endanger the heterogeneousity in Indonesia. Further, the character lacks of tolerance and the truth parameter is in the group.

Following this paradigm, heterogeneity is something that does not have a great opportunity to be appreciated and managed. In fact, Indonesia's heterogeneous is the highest in the world it has various of traditions, arts, culture, languages and ethnic groups. ${ }^{9}$ It is difficult to imagine how the nation's condition with high heterogeneity in the presence of Islamic radical groups. It is precisely that the presence of Islamic radical movements requires serious attention otherwise it would break the harmony existed for long ago.

Islamic radical continues to develop by entering various fields of life, including the higher education. They recruit new members in various ways. Several studies reveal that Islamic radical has been presented and extensively developed in universities in Indonesia. Despite of getting a response and rejection, Islamic radical activists continue to carry out their mission in various ways.

Research conducted by Sahri shows that at campus environment, including in Islamic higher education, they always have radical movements exist, both right and left movement. The conversion of State Institute for Islamic Studies (IAIN) to State Islamic University (UIN) turned out to be entrance for the seeds of radicalism. The emergence of new majors attracts high school/vocational school graduates. Some high school/vocational school graduates do not have adequate religious knowledge capital. In certain cases, they found religious diversity on campus. This spirit found fertile nursery fields when meeting radical organizations as Sahri's

Vol. 20, No. 1, May 2012, p. 80-82; M. Zaki Mubarak, "Dari NII ke ISIS: Transformasi Ideologi dan Gerakan dalam Islam Radikal di Indonesia Kontemporer", Epistemê, Jurnal Pengembangan IImu Keislaman Vol. 10, No. 1, 2015, p. 79.

9 Faisal Ismail, Panorama Sejarah Islam dan Politik di Indonesia..., p. 10-11. research demonstrate an Islamic political approach. ${ }^{10}$ Unlike Sahri's study, the present study demonstrates the deradicalization strategy applied at IAIN Tulungagung.

Sri Hadijah Arnus suggests that students of IAIN Kendari had a very heterogeneous background. She argued that heterogeneity is part of the wealth of life assets that must be appreciated. However, if the management was wrong, the diversity would turn into a disaster. One strategy for managing heterogeneity was through media literacy. At the applicative level, media literacy was believed as a fairly effective deradicalization strategy. ${ }^{11}$ Unlike her study which focuses on media literacy, the present study highlights the deradicalization strategy applied at IAIN Tulungagung. Therefore, even though they both talked about deradicalization and both of them are at IAIN, the differences are common in many ways.

The research conducted by Susanto at the Faculty of Science and Technology at UIN Syarif Hidayatullah shows that the students at the faculty are quite vulnerable to radicalism. Therefore it is necessary to make various efforts so the students do not participate and involve in Islamic radical. Susanto developed an independent learning material for Islamic Education (PAI) course that was believed to be able to carry out the function of deradicalization. ${ }^{12}$ Contrastly, followed research initiates the present study in terms of deradicalization strategies at IAIN Tulungagung.

Regarding to the previous studies, many of them focus on deradicalization within education environment. Even though many of them also conduct similar topic in universities, but the present study has its own perspective. Therefore, this study presents newer deradicalization strategy in university.

${ }^{10}$ Sahri, "Radikalisme Islam di Perguruan Tinggi Perspektif Politik Islam”, Jurnal Al-Daulah Vol. 6, No. 1, 2016.

"Sri Hadijah Arnus, "Dakwah yang Berliterasi Media: Upaya Deradikalisasi di Lingkup Kampus IAIN Kendari”, Jurnal Palita Vol. 2, No. 2, 2017.

${ }_{12}$ Susanto, "Bahan Belajar Mandiri Sebagai Suatu Model Modul Studi Islam Berwawasan Deradikalisasi Pemahaman Agama", Jurnal PERSPEKTIF Ilmu Pendidikan Vol. 30, No. 2, 2016. 


\section{Method}

This article is processed from the results analysis. qualitative method was employed in this study. This qualitative study was also followed with a phenomenological approach. This approach attempted to understand the meaning of events and their relationships with ordinary people in certain situations. ${ }^{13}$

The presence of researchers at the research site responded positively. However, due to the busyness of the informants, interviews were conducted several times whenever there was possible chance. The data traced in this study focused directly on data related to the research question. These data then processed according to the context of the journal article.

Data was collected through the three types of complementary methods, namely indepth interviews, participant observation, and documentation. Data analysis was performed before researcher entered the field. This analysis is carried out on data from preliminary studies that were used to determine the focus of the study, although it was temporary and tentative which would develop after the researcher enters and involves in the field. ${ }^{14}$ However, the next discussion more to be emphasized on data analysis activities in the field after the data were obtained by researcher through in-depth research. The data obtained were analyzed through two stages, namely single site data analysis and cross-site analysis. Single site data analysis was carried out through the analysis stages offered by Matthew B. Miles and A. Michael Huberman namely; data reduction, data display, and conclusion drawing and verifying. ${ }^{15}$

13 Lexy J. Moleong, Metodologi Penelitian Kualitatif, (Bandung: PT. Remaja Rosdakarya, 1993), p. 9.

${ }^{14}$ Sugiyono, Metode Penelitian Kuantitatif, Kualitatif, dan R \& D, (Bandung: Al-Fabeta, 2011), p. 245.

${ }_{15}$ Matthew B. Miles \& A. Michael Huberman, Qualitative Data Analysis: An Expanded Sourcebook, (London: SAGE Publication Ltd., 1994). Lihat juga A. Michael Huberman \& Matthew B. Miles, "Data Management and Analysis Methods", dalam Norman K. Denzim \& Yvona S. Lincoln (eds.), Handbook of Qualitative and Quantitative Research, (London: SAGE Publication, 1994), p. 429

\section{Radicalization and Deradicalization}

Islamic radical is not a new phenomenon at all. Movements that are identified as radical are always present at all times. They exist, grow, and develop themselves according to the context of the times. If reality is repressive, they use a strategy that is not confrontational. As the condition allow them to move, they develop themselves by involving into any field of activities.

Radicalism is also called fanaticism which also refers to "cognitive structure". It doesn't just show up. There are various factors that are related. In the community, radicalism emerges as a product of a long social communication. ${ }^{16}$

The Indonesian reformation seems to initiate the growth and development of Islamic radical. ${ }^{17}$ Today, Islamic radical movements involve in areas that have never been expected. They associate into various activities such as establishing organizations and carrying out various activities through education to the ideological infiltration. The spirit of developing the organization and ideology is so strong for Islamic radical activists.

The phenomenon of Islamic radical which is now spread increasingly cannot be left out of nowhere. A creative and systematic response is required so that the spread of Islamic radical is not increasingly rooted in society. Otherwise, the peaceful Indonesia might only be awakened as if the understanding of religion that developed in the community was a moderate understanding of religion.

Islamic radical is important to get an attention, because when the ideology of radicalism has been firmly rooted in a person or group of people, it will have real implications in life. This is because ideology can unite people who follow it to take action effectively. By focusing on the goals, the ideology aims to arouse feelings and encourage the emergence of actions from the drivers. While viewed from the dimension of strength, ideology has the

${ }^{16}$ Yudi Latif, Intelegensia Muslim dan Kuasa: Genealogi Intelegensia Muslim Indonesia Abad ke-20, (Bandung: Mizan, 2005), p. 209.

17 Sri Yunanto, Islam Moderat vs Islam Radikal, Dinamika Politik Islam Kontemporer, (Yogyakarta: Media Pressindo, 2018), p. xx. 
capacity to embrace and move the imagination and energy of its adherents. ${ }^{18}$

In a sense, Islamic radical is an understanding, ideology, or Islamic religious belief whose purpose is to make changes in society and the state that are carried out radically. This change aims to restore Islam as a life guidance, both for society and individuals. ${ }^{19}$ Changes made are revolutionary. They overturn the values that exist radically through violence and other extreme paths. ${ }^{20}$

Radicalization does not just happen. There are several stages until one can adopt a radical ideology. Gradually, radicalization occurs as the following; first, pre-radicalization. In this stage, one cannot be called a person who has embraced radical ideology. This is because activists involve to public and follow religious forums in general. Shortly, this stage is actually not dangerous because it is not as different as the situation of Muslims in general. However, there are initial indications lead to radical understanding.

second, the stage of self-identification. Someone begins to involve the condition as a radical candidate. Due to radical activists have recruited and involved to communities as their ideology the socialization model is relatively the same.Someone who has entered the group will continue to accept the doctrine intensively.

Third, the ideologization stage. At this stage there is an ideological transformation. The initial ideology adopted was changed. If someone initially has a moderate ideology, it can turn out to be radical. This ideology takes place continuously and intensively. Someone who has been involved in this third stage often hard to get away.

Fourth, the implementation. The radicals in this stage have deep roots. Radicalism has become internalized into ideology. Substantially there has been a change in radical ideas into

${ }_{18}$ Faisal Ismail, Panorama Sejarah Islam dan Politik di Indonesia..., p. 27.

19 Toto Suharto dan Ja'far Assagaf, “Membendung Arus Paham Keagamaan Radikal di Kalangan Mahasiswa PTKIN", Jurnal Al-Tahrir Vol. 14, No. 1, 2014, p. 162.

20 Marx Juergensmeyer, Teror Atas Nama Tuhan: Kebangkitan Global, Kekerasan Agama, (Jakarta-Magelang: Nizam Press \& Anima Publishing, 2000), p. 5. acts of violence using religious reasons. ${ }^{21}$ This phenomenon of Islamic radical has received the attention from many experts. One opinion asserts that radical people is arrogant. This arrogance is varied encompasses at the intellectual level that called absolutism or absolute opinion, at a social level that called exclusivism which alienate ordinary people, and at an emotional level that called fanaticism which is a loyalty to the characters or groups in excess. ${ }^{22}$ Mujiburrahman suggests that a religious person is a someone who understands religion like ready-made clothes. Though the clothes are made through a long process, religion in this case, true religion is a continued searching process". ${ }^{23}$

Thus, Islamic radical is the root of understanding, then implemented in action. The act of violence is a manifestation of Islamic radical. The actions performed is actually in contrast from the Islam ideology taught the peace. Even in broader context, the violence they commit is actually detrimental to Muslims as a whole.

The development of Islamic radical contradicts the spirit and ethos of Islamic intellectuals. Conducive intellectual atmosphere of Islam, creative generation, and productive scientific discourse are an ideal that ushered the Islamic world to progress. ${ }^{24}$ This reality is not on the agenda of Islamic radical groups. Their agenda is to build the world in their imagination.

Looking at geneological roots, Islamic radical arises due to various conditions. One of them is the condition of being marginalized by various life competitions, both on a global and local scale. The marginalized have a tendency not to have a comprehensive perspective on the issue. His perspective is black and white, thus does not appreciate the intellectual dimension.

At this point, Islamic education has a very important role. The role is related to, among other things, how to build an understanding of

${ }^{21}$ Sri Yunanto, Islam Moderat vs Islam Radikal..., p. 179.

${ }^{22}$ Mujiburrahman, Agama Generasi Elektronik, (Yogyakarta: Pustaka Pelajar, 2017), p. 7.

${ }^{23}$ Mujiburrahman, Agama Generasi Elektronik..., p. 8.

24 Nurcholish Madjid, Kaki Langit Peradaban Islam, (Jakarta: Paramadina, 2009), p. 31. 
reality objectively. Understanding that is indicated by radicalism must be neutralized, because it endangers the lives of Muslims as a whole. It is in this framework that Islamic education must design how to create an understanding of moderate Islam.

Islamic education, based on Fazlur Rahman's study, is a starting point in the framework of the realization of genuine Islamic weltanschauung. ${ }^{25}$ This means that Islamic education has a role that is not only conceptually but also operationally transformative. The fundamental role of education is to strengthen human resources through the internalization of knowledge, attitudes, behaviors, and skills that determine progress. Such idealization is not found in the imagination of those who adhere to Islamic radical.

The growth and development of Islamic radical also endangers the existence of Islamic education and the generation of the nation. ${ }^{26}$ Education can be threatened by its existence resulting no longer development of its functions and roles optimally. Many efforts to utilize the basic human potential as the basic spirit of Islamic teachings cannot be implemented because it is contrary to the spirit promoted by Islamic radical. Consequently, Islamic education must not remain silent. Efforts must be made to deradicalize intensively so that the existence of religious radicalism does not spread to various places.

Violence, as is often done by Islamic radical groups, it actually reflects the low level of education. ${ }^{27}$ Educated people are less likely to commit violence because internalization of values and knowledge gives them the opportunity to think comprehensively. Violence is carried out by those who see a problem from one perspective. Wisdom life is only obtained by those who are able to understand the problem by considering various aspects comprehensively.

The important role that can be conducted

\footnotetext{
${ }^{25}$ Fazlur Rahman, Islam, Sejarah Pemikiran dan Peradaban, Trans. (Bandung: Mizan, 2017), p. 384.

${ }^{26}$ Irwan Masduki, "Deradikalisasi Pendidikan Islam Berbasis Khazanah Pesantren”, Jurnal Pendidikan Islam Vol. 1, No. 2, 2012, p. 18.

${ }_{27}$ Sri Yunanto, Islam Moderat vs Islam Radikal..., p. 71.
}

in the education environment is deradicalization. Deradicalization has broad meaning and scope. One of them defines deradicalization as the formulation of Insani and Naispospos which determine deradicalization as early detection. This detection counteracting deradicalization from the beginning and targeting various potential layers with various forms relevant to each targeted group. ${ }^{28}$ Another opinion suggests that deradicalization is a systematic effort to build public awareness that narrowing fanaticism, fundamentalism and radicalism, they are potential to arouse terrorism. ${ }^{29}$

The choice of the deradicalization strategy is based on the idea that efforts to prevent radical movements through repressive-formalistic channels in reality are not fully effective. The patterns of repressive-formalistic handling can only temporarily stop the flow of radicalist movements. In addition, such patterns also have a great opportunity for the growth of similar currents when conditions permit. The path of violence that is pursued will only lead to other types of violence at different times. Irwan Masduki emphasizes that de-radicalization measures were needed to be more humanist Islamic education. ${ }^{30}$

At the applicative level, deradicalization programs cover at least three domains, namely the domain of national insights, religious insights, and entrepreneurial training. ${ }^{31}$ If, these three realms observed, they closely related to a fairly broad dimension. The dimensions of nationalism are given to foster a sense of nationalism and attitude towards the nation. The important religious insight develop which is also consistent with Islam in Indonesia, namely moderate Islam. While entrepreneurial training is performed to provide capital skills, this training is targeted

${ }^{28}$ Ismail Hasani dan Bonar Tigor Naispospos (eds.), Dari Radikalisme Menuju Terorisme: Studi Relasi dan Transformasi Organisasi Islam Radikal di Jawa Tengah \& D.I. Yogyakarta, (Yogyakarta: Pustaka Masyarakat Setara, 2012), p. 191.

${ }^{29}$ Nasir Abbas, "Berdayakan Potensi Masyarakat dalam Pemberantasan Terorisme”, Komunika Vol. 12, No. 7, 2011, p. 5.

${ }^{30}$ Irwan Masduki, "Deradikalisasi Pendidikan Berbasis Khazanah Pesantren”..., p. 1.

${ }^{31}$ Saefuddin Zuhri, Deradikalisasi Terorisme Menimbang Perlawanan Muhammadiyah dan Loyalitas Nahdlatul Ulama, (Jakarta: Daulat Press, 2017), p. 113. 
to those who are indicated by radicalism to be able to be independent in life after leaving the ideology of radicalism.

Regarding the segment of deradicalization program, there are seven segments. some of them are related to the world of education, namely: (1) segments for upper secondary school students and (2) student segments from Islamic campuses. ${ }^{32}$

Deradicalization cannot rely on one institution alone. All elements that have a role must carry out this task of deradicalization intensively. Thus, deradicalization becomes a joint movement involving various stakeholders in a systematic framework. In this context, in terms of education, especially Islamic religious colleges can carry out its role to the fullest.

\section{Deradicalization Strategy at IAIN Tulung Agung}

IAIN Tulungagung as an Islamic higher education institution is well aware of the dangers of Islamic radical. Islamic radical is quite intense in carrying out its activities. Colleges, including Islamic religious colleges, are the target of this Islamic radical movements. Therefore, various prevention efforts must be conducted intensively.

Prevention efforts are important since Islamic radical activities were more destructive than building. It is precisely because of this kind of activity that becomes an attraction so that more and becoming followers. Damaging it is easier. Hence, the idea of radicalism continued to get more supporters. They never think constructively and their thoughts are destructive. ${ }^{33}$

Consequently, various systematic deradicalization efforts have been carried out. The choice for deradicalization must be done carefully. Even though substantially deradicalization has a good goal, but if at the implementative level is not done carefully, there is an opportunity for something to be contrary to the deradicalization

\footnotetext{
${ }^{32}$ Saefuddin Zuhri, Deradikalisasi Terorisme Menimbang..., p. 116-117.

${ }^{33}$ Welcoming speech of Rector of IAIN Tulungagung, Mr. Maftukhin, in "Rapat Kerja Fakultas Ekonomi dan Bisnis Islam IAIN Tulungagung" in Crown Victoria Hotel Tulungagung, 15 March 2018.
}

spirit itself. Inappropriate deradicalization could initiate new radicalization. ${ }^{34}$

Formally and explicitly, no program detected with the name deradicalization at IAIN Tulungagung. However, there are programs that can be categorized in the frame of deradicalization.

First, IAIN Tulungagung has programs related to efforts to prevent the entry and development of radicalism among academics. This program is designed by involving competent outside parties among the forms of activities are presenting speakers from the National Counterterrorism Agency (BNPT). The speaker from BNPT provided a comprehensive explanation regarding the terrorism. They were presented during the Introduction to Academic and Student Culture (PBAK) activities. Their presence provides a lot of important information regarding terrorism. It is one of the initial efforts to fence off the campus, especially new students, from the notion of radicalism. Through this program, it is expected that students, especially new students, will not be easily persuaded to join Islamic radical groups ${ }^{35}$. This activity actually becomes the basis for the establishment of a visionary Islamic education system. The vision of Islamic education that is align with the future is the creation of an Islamic, populist, quality-oriented and diversity education system..$^{36}$ This kind of vision is important to be followed up in the framework of developing religious patterns based on inclusiveness, pluralism and multiculturalism. Hence, it eventually creates harmony life among religious diversity that is tolerant, inclusive and multicultural. This is important because with the embeddedness of such awareness, to a certain extent it will produce a highly religious paradigm. These all must be done at the level of how to bring religious education into a tolerant and inclusive paradigm. ${ }^{37}$

\footnotetext{
${ }^{34}$ Sri Yunanto, Islam Moderat vs Islam Radikal..., p. 196.

35 Interview with Abad Badruzaman, Vice Rector 3 IAIN Tulungagung, August, 2018.

${ }^{36}$ Mujamil Qomar, Pendidikan Islam Prospektif, (Tulungagung: IAIN Tulungagung Press, 2017), p. 22.

${ }^{37}$ Edi Susanto, "Pendidikan Agama Berbasis Multikultural: (Upaya Strategis Menghindari Radikalisme)”, KARSA Vol. IX, No. 1, 2006, p. 785.
} 
The portrayal of Islamic education including Islamic Higher Education such as IAIN Tulungagung is impossibly established if Islamic radical grows. Islamic radical will not talk about quality, let alone diversity. Their perspective is the truth of their own version. For a college, this is certainly a dangerous thing. The ideology of Islamic radical adopted from various Middle Eastern countries has proven not to make progress. It is precisely the countries where dominant Islamic radical is torn apart. ${ }^{38}$

Second, IAIN Tulungagung is a campus that has a unique program. The program is called Madin (Madrasah Diniyah) as a non-formal Islamic education program. According to the Rector of IAIN Tulungagung, in Indonesia, especially at Islamic higher education (PTKIN), there are two models of relations between universities and Islamic boarding schools. The first model is a model developed by Islam State University (UIN) Maliki in Malang. At the application level, all new students enroll the boarding school. They have been being santri ma'had (students who stay at boarding school) for a year. Their daily activities are exactly as the same as activities in the boarding schools. ${ }^{39}$

The second model is a model developed by IAIN Purwokerto. At the level of practice, all new students for one year are deposited in various existing Islamic boarding schools. They all have to be santri (student who focuses on learning Islamic education) for a year. This program was decided because IAIN Purwokerto does not have a special ma'had (boarding school) as UIN Maliki Malang's . By being entrusted to various Islamic boarding schools in IAIN Purwokerto, students are expected to gain knowledge, insights, skills, and important matters relating to religion. ${ }^{40}$

\footnotetext{
${ }^{38}$ Interview with Abad Badruzaman, Vice Rector 3 IAIN Tulungagung, September 20, 2018.

39 According to Khozin, This relationship model is an advantage in UIN Maliki Malang because this model is the one and only in Indonesia. There is no other Islamic higer educations (PTKIN) that develops this kind of relationship. see Khozin, Pengembangan Ilmu di Perguruan Tinggi Keagamaan Islam, Konstruksi Kerangka Filosofis dan Langkah-langkahnya, (Jakarta: Kencana, 2016), p. 177.

40 This model is referred to as a "partnership model", namely IAIN Purwokerto build partners with various existing Islamic boarding schools. A more detailed discussion of this partnership model can be read at Siti Iskarimah, "Model
}

IAIN Tulungagung, according to the Rector, is not possible to imitate the model of UIN Maliki Malang because it does not have dormitory to accommodate all new students. IAIN Tulungagung requires more cost to make similar model as UIN Maliki Malang. In addition, it also takes longer because building a dormitory cannot be done quickly. The considerations, such as a limited budget, and area inadequacy, makes the IAIN Tulungagung is unlikely to take a model like that developed by UIN Maliki Malang.

On the other hand, IAIN Tulungagung also cannot fully adopt the partnership model between IAIN and Islamic boarding schools around IAIN as developed by IAIN Purwokerto due to the sociological context differs. The number of Islamic boarding schools around IAIN Tulungagung was not as many as IAIN Purwokerto. Additionally, with a large number of students, the existence of Islamic boarding schools around IAIN Tulungagung was unlikely to be able to accommodate them.

It is precisely for this reason that the IAIN Tulungagung then developed a separate model that was different from UIN Maliki of Malang and IAIN Purwokerto. The Rector called this model as a new system that is different from UIN Maliki of Malang and IAIN Purwokerto. The system is Madin (Madrasah Diniyah) as a nonformal Islamic education program. "The language in the salafiyah Islamic boarding school is called the kalong system, the santri kalong, or the santri nduduk. This system exists in traditional Islamic boarding schools. The mechanism, all new students must follow this program according to their own abilities. whether they still read and write the Holy Quran or have joined the school according to their abilities. ${ }^{41}$

This Madrasah Diniyah program is not possible to be applied during lecturing program. If that is done, based on the analysis carried out, the possibility is also less effective. Besides that, the time is also impossible to be implemented simultaneously. Based on a variety of careful

\footnotetext{
Kemitraan Program Pesantrenisasi IAIN Purwokerto", Thesis, Postgraduate of IAIN Purwokerto, 2017.

${ }^{41}$ Interview with Maftukhin, the Rector of IAIN Tulungagung, October 10, 2018.
} 
considerations and analysis, the Madrasah Diniyah program was developed by IAIN Tulungagung in the morning, which is at 07.00 to $08.40 \mathrm{AM}$. During this hour, all of regular lectures are postponed, then change the lecturing process that should be conducted in morning to afternoon. At 7:00 $\mathrm{AM}$ to 8:40 AM, no regular lectures performed, all activities only focus on reciting the Holy Quran Madrasah Diniyah. ${ }^{42}$ The instructor of Madrasah Diniyah (Madin) is not a lecturer at IAIN Tulungagung. All the teachers are coming from outside, namely those who have taught in various Madrasah Diniyah. Therefore, in terms of learning, the traditions developed remain the same. Male teachers teach as they do in their respective villages. They teach by using their distinctive clothing and no need to follow campus clothing system.

According to the Rector, the implementation of Madrasah Diniyah on the one hand was one form of tafaqquh fiddîn (Understanding the religion in deep). While on the other hand, Madrasah Diniyah has a role that is quite effective in forming the character of courtship. Further, both are important. "It is not only how new students participate in Madrasah Diniyah program to have better religious understanding, but also their religious practices. So that prevention of radicalism is based on the religious tradition that we build together", said the Rector. ${ }^{43}$

The policy of Madrasah Diniyah, in a certain perspective, was actually the endeavor of IAIN Tulungagung in reading the dynamics and development of society. Education which was not consider this dimension would lose its relevance and be abandoned by society. The relationship between education and society was reciprocal. This aspect showed that the relations between the two were closely related.

In this regard, Islamic education is important to review its position. In this perspective, Islamic education required to review its orientation. If needed, reorientation must be done so that it is in line with the existing dynamics. One

${ }^{42}$ Interview with Maftukhin, the Rector of IAIN Tulungagung, October 10, 2018.

${ }^{43}$ Interview with Maftukhin, the Rector of IAIN Tulungagung, October 10, 2018. orientation that seems important to consider is theoanthropocentric. Islamic education must consider this orientation. At the operational level, theoanthropocentric refered to the balance of relations with God (hablun minallah) and relations with humans (hablun minannâs). Relationship with God aims to increase faith and piety. The emergence of various issues of morality in the world of education shows that the fundamental task of education has not been able to run optimally.

The basic task of education, in another context, tries to shape human beings with character. Human character is a human who has positive moral qualities. This meaning implicitly builds understanding, traits, and behavior patterns based on positive or good moral dimensions, not negative or bad ones. Character education, thus, is a planned and systematic effort to make students recognize, aware, have concern, and try to internalize the values so that students behave as our human beings. ${ }^{44}$ Another opinion suggests that character education is a system of planting behavioral values (character) to school citizens which includes the components of knowledge, awareness or willingness, and actions to implement these values, both towards God Almighty, theirselves, others, environment, and nationality so that we become our human beings. Character education at the institutional level resulting the formation of school culture, namely the values that underlie behavior, tradition, daily habits, and symbols that are practiced by all school members, and the community around the school. School culture is a characteristic and the image of the school in the wider community.

Based on the aforementioned understanding , character education is an education that develops cultural values and national character in students. Therefore they have values and character as their character, apply these values in their lives, as members of society, and citizens who are religious, nationalist, productive and creative. In contrast, the relationship between people must also get adequate attention. The relationship with

44 D. Yahya Khan, Pendidikan Karakter Berbasis Potensi Diri, Mendongkrak Kualitas Pendidikan, (Yogyakarta: Pelangi Publishing, 2010), p. 2-3. 
humans aims to improve the quality of social interaction, social awareness, social solidarity, and social piety. The balance orientation of this relationship must be operationalized in the curriculum and learning strategy. 45

The balance of these two relations is very important to get attention because the imbalance of relations will have implications for the formation of a figure that is very likely trapped at the extreme pole. The interpretation of the narrow teachings of Islam makes a child having a radical character, while not caring socially makes a person deny the dimensions of social relations.

Islamic radical arises due to a monolithic perspective. Even though today's reality is heterogeneous. The monolithic perspective as embraced by Islamic radical groups is dangerous for Indonesia's future. The important thing to be developed is to appreciate heterogeneous reality productively-constructively. The initial step is through individual channels ${ }^{46}$ and what can be done is education.

Another important orientation to be considered is multiculturalism. Indonesia is a country with multicultural society. Multicultural reality must be understood creatively and productively. Misunderstanding of multicultural reality can endanger the joint life of the Indonesian people as a whole. The emergence of conflicts and violence is caused by one of them due to the lack of understanding of multiculturalism. ${ }^{47}$ As a consequence, multicultural based Islamic education is important to be developed to create mutual respect. ${ }^{48}$

This Madrasah Diniyah program is called a program that contains the hidden curriculum. This occurs because the instructors of the Madrasah Diniyah are the ustad (teacher) of the Islamic boarding school. They have very good religious abilities. This good knowledge was an important capital when they teach students in Madrasah

\footnotetext{
${ }^{45}$ Mujamil Qomar, Pendidikan Islam Prospektif..., p. 24.

${ }^{46}$ Ulya, "Logika Wujud Sadra, Meretas Nalar Radikalisme Beragama”, Jurnal Theologia Vol. 27, No. 1, 2016, p. 18.

47 Zamroni, Pendidikan dan Demokrasi dalam Transisi, (Jakarta: PSAP, 2007), p. 267.

48 Irwan Masduki, "Deradikalisasi Pendidikan Berbasis Khazanah Pesantren”, p. 8.
}

Diniyah program. Furthermore, the ustad (teacher) who run this Madrasah Diniyah program were expected to provide sufficient knowledge of religion to students so that they are not easily invited to participate in the teachings of Islamic radical. ${ }^{49}$

Third, fortifying the entry of Islamic radical through rules. Its form, for example, is the Student Ethics Code (KEM). According to Abad Badruzaman, Vice Rector 3, KEM is not only narrative, but also gives operational examples. For instance, an explanation of clothing that is allowed on campus. In order for KEM to be better known by students, KEM is uploaded on the IAIN Tulungagung website. In KEM, the rules are very clear and the following example. Based on the KEM, the leadership can normatively take action if there are students who are dressed not refer to the rules in the KEM. ${ }^{50}$

According to Vice Rector 1, efforts to fortify the spread of Islamic radical in IAIN Tulungagung are actually carried out intensively and structured. Since students enroll-through PBAK-then there are rules contained in KEM, until the graduation was framed in the framework of preventing the spread of Islamic radical. Even a photograph of a diploma for students who are going to graduate, their face photo must be open and not allowed to wear the veil. This is because the veil is identical to Islamic radical. In addition, it is also consistent with the general rules of the diploma that requires a visible face. ${ }^{.1}$

This fortifying effort can be understood in a sociological and psychological context. There are a lot of new students at IAIN Tulungagung. In 2018 there are 5605 new students. They are all young and most of them do not have emotional maturity yet. Such conditions are easily invited to join Islamic radical groups. It is precisely for this reason that Islamic religious colleges such as IAIN Tulungagung have an important role to fortify themselves from the Islamic radical sect.

\footnotetext{
49 Interview with Abd Aziz, the Vice Rector 1 of IAIN Tulungagung, September 29, 2018.

${ }^{50}$ Interview with Abad Badruzaman, the Vice Rector 3 of IAIN Tulungagung, August 25, 2018.

51 Interview with Abd Aziz, the Vice Rector 1 of IAIN Tulungagung, September 29, 2018.
} 
In addition to the rules, the important thing to strengthen is Islamic religious education..$^{52}$ Regarding this aspect, it is important for Islamic education institutions to reflect on their vision. Sri Yunanto consider Islamic education is currently dealing with a crisis of direction and vision. The implication is that Islamic education has not been able to formulate the direction and objectives to be achieved based on Islamic teachings. The dimensions of resource empowerment that are the basis of progress have been neglected. The methodology developed by Islamic education actually eliminated aspects of spirit of inquiry, enthusiasm for research, and reading. ${ }^{53}$ This criticism was not to be debated. The important aspect was how to position this criticism as a medium for self-reading. If indeed the reality is like the one, then it must be fixed immediately. However, if it is not like the one, the criticism is positioned as an anticipatory media so that such things do not happen.

Fourth, support all activities related to the understanding and spread of Islamic moderate. Activities may vary, for example seminar activities. In the seminar activity, figures were presented with Islamic moderate paradigms. In 2018, IAIN Tulungagung held a national seminar on Islamic moderate. This seminar that was open to the public gets very high appreciation from the participants. The number of participants who attended exceeded the target. The seats provided could not accommodate the number of participants. The participants wantedto sit and stood in the available spaces. ${ }^{54}$

Fifth, take advantages of every opportunity that allows to explain the importance of Islamic moderate. The Rector, vice Rector, Deans, lecturers and all academics are expected to explain the significance of Islamic moderate and the dangers of Islamic radical. This kind of method is believed to be able to provide knowledge, understanding and awareness of the dangers of Islamic radical. 55

52 Suharto dan Assagaf, "Membendung Arus Paham Keagamaan Radikal”, Jurnal Al-Tahrir Vol. 14, No. 1, 2014, p. 165.

${ }^{53}$ Sri Yunanto, Islam Moderat Vs Islam Radikal..., p. 53.

54 Interview with Abad Badruzaman, the Vice Rector 3 of IAIN Tulungagung, August 25, 2018.

55 Interview with Abad Badruzaman, the Vice Rector 3 of
Sixth, optimize local wisdom. The local wisdom in Tulungagung is varied. Vice Rector 1 of IAIN Tulungagung said that local wisdom that explored and developed by IAIN Tulungagung had a direct function. One example is to invite parents of new students to campus. Invitations from the parents to the campus are rarely to happen by other universities. This model is actually adapted and developed from Islamic boarding schools. They parents send their students to the campus to be educated. The leadership in his speech provided an understanding of mutual cooperation, between parents and campus institutions, both in terms of payment and others explained. If there is behavior or something different from before from their students, parents are expected to report to the campus so that proper action can be undertook.

Another form of local wisdom is cooperation with the owners of dormitories around campus and the caregivers of Islamic boarding schools around the campus. They were invited to a special meeting. The goal is that they also take care of the students who are there. The campus even begged the boarding house father to have a spiritual shower in the boarding house to ward off the entry of Islamic radical ideology. ${ }^{56}$

Seventh, creating learning environment that supports deradicalization programs. This environment is manifested in a religious atmosphere that is built systematically. Every beginning of the semester, all academics are invited to pray together in each faculty. Besides that, every Friday, the activity is reciting the Holy Quran. Before the learning process starts, all lecturers were conditioned to pray together. All of this is expected to support the creation of a conducive environment and prevent the involvement of Islamic radical. ${ }^{57}$

A conducive environment is important because students spend most of their time on campus. A research conducted by Achmad Habibullah shows that the educational environment can be

\footnotetext{
IAIN Tulungagung, August 25, 2018.

56 Interview with Abd Aziz, the Vice Rector 1 of IAIN Tulungagung, September 29, 2018.

57 Interview with Fathul Mujib, the Vice Dean 1 of Tarbiyah and Pedagogy Faculty, October 19, 2018.
} 
a field of seedling for the seeds of radicalism. Spiritual Islamic activists (Rohis) in high school, in the eight cities, reveal that they generally had a 'spirit of religion'. This spirit, in the context of socio-religious attitudes, is actually an important phenomenon to be appreciated. However, it is still necessary to develop a critical attitude in addressing this phenomenon because it is possible that this spirit will develop into a radical religious attitude..$^{58}$

Deradicalization-based learning is also important to be considered. One of the keys to successful deradicalization is its implementation at the learning level. Maximum learning will be able to realize three basic functions as follow. (1) as an endeavor in shaping the noble character of students that manifested in the quality of their faith and piety. (2) as an effort to suppress, limit, and eliminate the movement space of the perpetrators of terrorism. (3) as an effort to strengthen Muslims who have politeness, friendliness and peace. ${ }^{59}$

Nevertheless, higher education still has to develop a critical attitude. Critical attitude provides an opportunity for all components in Islamic education not only to undergo a normative-dogmatic learning process, but also to use critical thinking. This critical way of thinking provides an opportunity for all parties to make an assessment with the objective in improving and achieving educational goals. The purpose of education is influenced by the process of achievement. All of these aspects are always positioned as a part that is not separated in the framework of maintaining education so that it does not fall on the radical path. This is important, because Islamic radical comes in many ways. If we are not careful, infiltration of radical ideologies can enter through the school without being realized by the concerned parties. ${ }^{60}$

${ }^{58}$ Achmad Habibullah, "Sikap Sosial Keagamaan Rohis di SMA pada Delapan Kota di Indonesia”, Edukasi Vol. 12, No. 3, 2014, p. 411.

${ }^{59}$ Novan Ardy Wiyani, "Pendidikan Agama Islam Berbasis Anti Terorisme di SMA, Jurnal Pendidikan Islam, Vol. 2, No. 1, 2013, p. 75.

${ }^{60}$ Ngainun Naim, "Pendidikan Aswaja Sebagai Strategi Deradikalisasi”, Walisongo Vol. 23, No. 1, 2015, p. 69-88.
Thus, educational institutions, especially Islamic education institutions, are important to pay attention to this dimension. The basic task is to build a conducive educational environment that allows for the realization of knowledgeable scholars who have a sharp perspective in understanding the reality of humanity objectively. ${ }^{61}$

\section{Conclusion}

Islamic radical is a reality that must be faced objectively. Its rapid growth and development after the fall of the New Order has provided its own color in the dynamics of socio-religious life in Indonesia. His character who tends to use violence has caused widespread unrest. Islam in Indonesia which for hundreds of years was known as friendly Islam experienced a shift of face. Sociologically, Islamic radical groups are actually only a minority. However, they are active in the movement by utilizing various existing media while Islamic mainstream has relatively little active-creative-constructive response to existing developments. It is precisely for this reason that Islamic radical is the face of Islam as a whole.

Islamic education, as practiced by the IAIN Tulungagung, is important in active responding creatively to this phenomenon. Deradicalization is one of the important strategies to be used as an important part of the strategy to fortify the development of Islamic radical. Through the deradicalization strategy, it is expected that Islamic education brings moderate Islam in accordance with the character of Islam in Indonesia that exists has long time ago.

\section{References}

A'la, Abd., "The Genealogy of Muslim Radicalism in Indonesia: A Study of the Roots and Characteristics of the Padri Movement", Journal of Indonesian Islam, Vol. 2, No. 2, 2008.

Abbas, Nasir, "Berdayakan Potensi Masyarakat dalam Pemberantasan Terorisme", Komunika, Vol. 12, No. VII, 2011.

\footnotetext{
${ }^{61}$ Mujamil Qomar, Pendidikan Islam Prospektif..., p. 19.
} 
Arnus, Sri Hadijah, "Dakwah yang Berliterasi Media: Upaya Deradikalisasi di Lingkup Kampus IAIN Kendari", Jurnal Palita, Vol. 2, No. 2, 2017.

Azra, Azyumardi, "Sekapur Sirih: Politik Islam Indonesia Kontemporer", dalam Sri Yunanto, Islam Moderat vs Islam Radikal, Dinamika Politik Islam Kontemporer, Yogyakarta: Media Pressindo, 2018.

Bagir, Haidar, Islam Tuhan Islam Manusia: Agama dan Spiritualitas di Zaman Kacau, Bandung: Mizan, 2017.

Habibullah, Achmad, "Sikap Sosial Keagamaan Rohis di SMA pada Delapan Kota di Indonesia", Edukasi, Vol. 12, No. 3, 2014.

Hasani, Ismail dan Tigor Naispospos, Bonar (eds.), Dari Radikalisme Menuju Terorisme: Studi Relasi dan Transformasi Organisasi Islam Radikal di Jawa Tengah \& D.l. Yogyakarta, Yogyakarta: Pustaka Masyarakat Setara, 2012.

Ismail, Faisal, Panorama Sejarah Islam dan Politik di Indonesia, Sebuah Studi Komprehensif, Yogyakarta: IRCISoD, 2017.

Juergensmeyer, Marx, Teror Atas Nama Tuhan: Kebangkitan Global, Kekerasan Agama, JakartaMagelang: Nizam Press \& Anima Publishing, 2000.

Khan, D. Yahya, Pendidikan Karakter Berbasis Potensi Diri, Mendongkrak Kualitas Pendidikan, Yogyakarta: Pelangi Publishing, 2010.

Latif, Yudi, Intelegensia Muslim dan Kuasa: Genealogi Intelegensia Muslim Indonesia Abad ke-20, Bandung: Mizan, 2005.

Madjid, Nurcholish, Kaki Langit Peradaban Islam, Jakarta: Paramadina, 2009.

Masduki, Irwan, "Deradikalisasi Pendidikan Islam Berbasis Khazanah Pesantren”, Jurnal Pendidikan Islam, Vol. 1, No. 2, 2012.

Miles, Matthew B. \& Huberman, A. Michael, Qualitative Data Analysis: An Expanded Sourcebook, London: SAGE Publication Ltd., 1994.

"Data Management and Analysis Methods", dalam Norman K. Denzim \& Yvona S. Lincoln (eds.), Handbook of Qualitative and Quantitative Research, London: SAGE Publication, 1994.

Moleong, Lexy J., Metodologi Penelitian Kualitatif, Bandung: PT. Remaja Rosdakarya, 1993.
Mubarak, M. Zaki, “Dari NII ke ISIS: Transformasi Ideologi dan Gerakan dalam Islam Radikal di Indonesia Kontemporer", Epistemê, Jurnal Pengembangan Ilmu Keislaman, Vol. 10, No. 1, 2015.

Mujiburrahman, Agama Generasi Elektronik, Yogyakarta: Pustaka Pelajar, 2017.

Naim, Ngainun, "Pendidikan Aswaja Sebagai Strategi Deradikalisasi", Walisongo, Vol. 23, No. 1, 2015.

Noorhayati, Siti Mahmudah, "Pendidikan Multikultural di Pesantren (Upaya Membendung Radikalisme di Indonesia)", Madania, Vol. 21, No. 1, 2017.

Qomar, Mujamil, Pendidikan Islam Prospektif, Tulungagung: IAIN Tulungagung Press, 2017. Rahman, Fazlur, Islam, Sejarah Pemikiran dan Peradaban, Bandung: Mizan, 2017.

Rokhmad, Abu, "Radikalisme Islam dan Upaya Deradikalisasi Paham Radikal", Walisongo, Jurnal Penelitian Sosial Keagamaan, Vol. 20, No. 1, 2012.

Rubaidi, "Variasi Gerakan Radikal Islam di Indonesia”, Analisis, Vol. 11, No. 1, 2017.

Sahri, "Radikalisme Islam di Perguruan Tinggi Perspektif Politik Islam”, Jurnal Al-Daulah, Vol. 6, No. 1, 2016.

Sugiharto, Bambang, "Ilmu dan Agama dalam Kurikulum Perguruan Tinggi”, dalam Zainal Abidin Bagir, Jarot Wahyudi, dan Afnan Anshori (eds.), Integrasi Ilmu dan Agama, Interpretasi dan Aksi, Bandung: Mizan, 2005.

Sugiyono, Metode Penelitian Kuantitatif, Kualitatif, dan R \& D, Bandung: Al-Fabeta, 2011.

Suharto Toto dan Assagaf, Ja'far, “Membendung Arus Paham Keagamaan Radikal di Kalangan Mahasiswa PTKIN", Jurnal Al-Tahrir, Vol. 14, No. 1, 2014.

Susanto, "Bahan Belajar Mandiri Sebagai Suatu Model Modul Studi Islam Berwawasan Deradikalisasi Pemahaman Agama”, Jurnal PERSPEKTIF Ilmu Pendidikan, Vol. 30, No. 2, 2016.

Susanto, Edi, "Pendidikan Agama Berbasis Multikultural: Upaya Strategis Menghindari Radikalisme", KARSA, Vol. IX, No. 1, 2006.

Ulya, "Logika Wujud Sadra, Meretas Nalar Radikalisme Beragama", Jurnal Theologia, Vol. 27, No. 1, 2016. 
Wiyani, Novan Ardy, "Pendidikan Agama Islam Berbasis Anti Terorisme di SMA", Jurnal Pendidikan Islam, Vol. 1, No. 2, 2012.

Yunanto, Sri, Islam Moderat vs Islam Radikal, Dinamika Politik Islam Kontemporer, Yogyakarta: Media Pressindo, 2018.
Zamroni, Pendidikan dan Demokrasi dalam Transisi, Jakarta: PSAP, 2007.

Zuhri, Saefuddin, Deradikalisasi Terorisme Menimbang Perlawanan Muhammadiyah dan Loyalitas Nahdlatul Ulama, Jakarta: Daulat Press, 2017. 